\title{
Morphology, histology and steroid hormones of the gonads in intersex pigs
}

\author{
R. H. F. Hunter, T. G. Baker* and B. Cook $\dagger$
}

School of Agriculture, University of Edinburgh, West Mains Road, Edinburgh EH9 3JG;

* Department of Obstetrics and Gynaecology, University of Edinburgh, Edinburgh EH3 $9 E W$, and $†$ Department of Steroid Biochemistry, University of Glasgow, Glasgow G4 OSF, U.K.

\begin{abstract}
Summary. Studies of 3 genetically female, intersex pigs revealed that only one showed oestrous cycles and lordosis, the other 2 exhibited various components of male sexual behaviour. Each uterus was a patent bicornuate structure, but 5 of the oviducts were incompletely formed. Two of the animals had bilateral ovotestes, whilst the third had a functional ovary on the right and an ovotestis on the left. The small ovarian portion of each ovotestis contained Graafian follicles which did not respond to a systemic injection of PMSG. The major portion of each ovotestis consisted of extensive interstitial tissue and seminiferous tubules devoid of germ cells. A structure closely resembling an epididymis adjoined the ovotestes.

Concentrations of oestradiol and progesterone in plasma corresponded with those expected in the follicular phase of an oestrous cycle, but concentrations of testosterone represented approximately one-tenth of the values found in mature boars.
\end{abstract}

\section{Introduction}

Anatomical aberrations of the 'female' reproductive tract and gonads associated with the intersex condition have been documented for a range of mammals (reviews by Biggers \& McFeely, 1966; Biggers, 1968; Short, 1969; Bishop, 1972), and there is especially useful information for farm animals in which apparent infertility or sterility has led to the identification of structural anomalies before slaughter (Deas, Melrose, Reed, Vandeplassche \& Pidduck, 1979). Intersex pigs, here referred to as animals with at least one ovo-testis and disturbances of the Müllerian duct system, have been the subject of a detailed review by Breeuwsma (1970), and the sex chromosome constitution of such animals is invariably XX. An intersex condition is observed in 1-2\% of 'gilts' in the closed pig-breeding herd of the Edinburgh School of Agriculture, and in 'females' allocated for physiological studies it has either been suspected on the grounds of genital morphology and aggressive behaviour or revealed during exploratory laparotomy. The following report concerns three instances for which we have a detailed photographic record of some of the anomalies.

\section{Materials and Methods}

The gilts, all purebred Large White, had been obtained at a liveweight of approximately $90 \mathrm{~kg}$, and were checked daily with a boar to determine periodicity of oestrus. In the absence of detectable cycles after 3-4 weeks of testing, animals $\mathrm{K} 12$ and $\mathrm{H} 41$ were given a single 
subcutaneous injection of 1000 i.u. PMSG (Folligon; Intervet) with the objective of stimulating ovarian activity.

The vulva and clitoris were examined in each animal, and one or more blood samples taken from a prominent ear vein for use in karyotype analysis and/or for steroid estimations.

The gilts were subjected to mid-ventral laparotomy under anaesthesia induced with pentobarbitone sodium and maintained by a mixture of halothane, nitrous oxide and oxygen. The reproductive tract was examined and photographed, and in one instance an unsuccessful attempt was made to catheterize the veins associated with an obvious ovo-testis; instead, further blood samples were taken from an ear vein.

The reproductive tracts were recovered at slaughter 2-6 days after laparotomy: within 20 min of evisceration, portions of gonadal and adjoining duct tissue were removed for histology or frozen at $-40^{\circ} \mathrm{C}$ for subsequent extraction and hormonal estimation. Fixation of tissues was in Bouin's aqueous fluid followed by dehydration in ethanol and then embedding in paraffin wax. Sections cut at $6 \mu \mathrm{m}$ were stained with haematoxylin and eosin.

Oestradiol, progesterone and testosterone concentrations were measured in plasma by the radioimmunoassays previously described (Cook, Hunter \& Kelly, 1977). Coefficients of variation were less than $10 \%$ within assays and less than $16 \%$ between assays. The sensitivities of the assays for oestradiol, testosterone and progesterone were 10,11 and $50 \mathrm{pg} / \mathrm{tube}$, respectively. Androstenedione and oestrone, for which routine radioimmunoassays were not conveniently available, were detected by gas-liquid chromatography. Ether extracts of tissue were evaporated to dryness, applied to thin-layer chromatography plates (pre-coated t.l.c. plates, silica gel 60, F-254; Merck, Darmstadt) and developed in ether : ethyl acetate $(5: 2 \mathrm{v} / \mathrm{v})$. Zones corresponding to androstenedione and oestrone were removed, eluted with ethanol, and examined in a Pye 104 gas chromatograph equipped with an auto-solids injection attachment. A glass column, $7 \mathrm{~m}$ long and $4 \mathrm{~mm}$ i.d., was packed with 3\% SP 2100 on Supelcoport for the separation. The column was run at $235^{\circ} \mathrm{C}$ with nitrogen as carrier gas. Flame ionization detection was used.

Karyotype analysis was undertaken by Dr Ann Chandley and Judith Fletcher of the M.R.C. Clinical and Population Cytogenetics Unit, Western General Hospital, Edinburgh. Karyotypes were prepared by a modification of the whole blood microtechnique, and air-dried chromosome spreads (10-30 per animal) and subsequent banding techniques followed the method of Buckland, Fletcher \& Chandley (1976).

\section{Results}

Observations are summarized in Tables 1 and 2 . All three animals were genetic females, having $2 \mathrm{X}$ chromosomes and 36 autosomes $(2 \mathrm{n}=38)$.

\section{Behaviour}

One of the animals (B17) had a series of 21-day oestrous cycles, and at each period of oestrus showed lordosis and stood for mounting by the boar. However, intromission was not achieved due to the very small vulva which did not swell detectably during oestrus.

Neither of the other two animals (K12 and H41) showed oestrous cycles or sexual behaviour characteristic of normal gilts and sows, whereas both had a marked tendency towards aggressive behaviour in the presence of mature males and courtship behaviour with oestrous females. When penned with a mature male, both showed a champing of the jaws, extensive salivary froth, and frenzied fighting behaviour typical of a boar. When penned with an oestrous female, by contrast, both nudged and butted the flanks and rear quarters of the female. In a contact period of 20-25 min, only H41 mounted the oestrous female. 
Table 1. Summary of observations on three intersex pigs

\begin{tabular}{|c|c|c|c|c|c|c|}
\hline \multirow[b]{2}{*}{ Animal } & \multirow{2}{*}{$\begin{array}{l}\text { Sex } \\
\text { chromosome } \\
\text { constitution }\end{array}$} & \multirow{2}{*}{$\begin{array}{c}\text { Hormone } \\
\text { treatment } \\
\text { before } \\
\text { slaughter }\end{array}$} & \multirow[b]{2}{*}{$\begin{array}{c}\text { Sexual } \\
\text { behaviour }\end{array}$} & \multirow[b]{2}{*}{$\begin{array}{l}\text { Oestrous } \\
\text { cycle }\end{array}$} & \multicolumn{2}{|c|}{ Condition of } \\
\hline & & & & & $\begin{array}{c}\text { Genital } \\
\text { tract }\end{array}$ & Gonads \\
\hline B17 & $\mathrm{XX}$ & None & $\begin{array}{l}\text { Typical female; stood } \\
\text { for mounting by boar }\end{array}$ & $\begin{array}{l}\text { Normal, } \\
\text { 21-day } \\
\text { interval }\end{array}$ & $\begin{array}{l}\text { Normal bicornu- } \\
\text { ate uterus; } \\
\text { vestige of left } \\
\text { oviduct at } \\
\text { isthmus; intact } \\
\text { right oviduct }\end{array}$ & $\begin{array}{l}\text { Ovotestis on left; } \\
\text { normal ovary } \\
\text { on right }\end{array}$ \\
\hline K 12 & $\mathrm{XX}$ & $\begin{array}{l}1000 \text { i.u. } \\
\text { PMSG }\end{array}$ & $\begin{array}{l}\text { Atypical; masculine, } \\
\text { aggressive behaviour; } \\
\text { would not mount } \\
\text { oestrous female }\end{array}$ & Not shown & $\begin{array}{l}\text { Normal bicornu- } \\
\text { ate uterus; } \\
\text { portion of ovi- } \\
\text { ducal isthmus } \\
\text { and Wolffian } \\
\text { tissue on both } \\
\text { sides }\end{array}$ & Two ovotestes \\
\hline H41 & $\mathrm{XX}$ & $\begin{array}{l}1000 \text { i.u. } \\
\text { PMSG }\end{array}$ & $\begin{array}{l}\text { Atypical; masculine, } \\
\text { aggressive behaviour } \\
\text { and also mounted } \\
\text { oestrous female }\end{array}$ & Not shown & $\begin{array}{l}\text { Normal bicornu- } \\
\text { ate uterus; } \\
\text { portion of } \\
\text { isthmus and } \\
\text { Wolffian tissue } \\
\text { on both sides }\end{array}$ & Two ovotestes \\
\hline
\end{tabular}

Table 2. The concentration of steroid hormones in peripheral blood (mean and range in parentheses), gonadal or epididymal tissue (mean \pm s.e.m.) of 3 intersex pigs

\begin{tabular}{|c|c|c|c|c|c|c|c|c|c|}
\hline \multirow[b]{2}{*}{ Animal } & \multicolumn{3}{|c|}{ Blood plasma $(\mathrm{pg} / \mathrm{ml})$} & \multicolumn{3}{|c|}{ Gonadal tissue $(\mathrm{ng} / \mathrm{g})$} & \multicolumn{3}{|c|}{ Epididymal tissue (ng/g) } \\
\hline & $\begin{array}{l}\text { Testo- } \\
\text { sterone }\end{array}$ & Oestradiol & $\begin{array}{c}\text { Pro- } \\
\text { gesterone }\end{array}$ & $\begin{array}{l}\text { Testo- } \\
\text { sterone }\end{array}$ & Oestradiol & $\begin{array}{c}\text { Pro- } \\
\text { gesterone }\end{array}$ & $\begin{array}{l}\text { Testo- } \\
\text { sterone }\end{array}$ & Oestradiol & $\begin{array}{l}\text { Pro- } \\
\text { gesterone }\end{array}$ \\
\hline B17 & $\begin{array}{c}304 \\
(112-425)\end{array}$ & $\begin{array}{c}11 \cdot 8 \\
(8 \cdot 0-24.0)\end{array}$ & $<50$ & 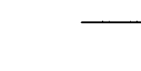 & 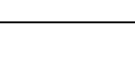 & Not av & ilable - & $c_{1}$ & - \\
\hline K 12 & $\longrightarrow$ & Not available & $e-$ & $\begin{array}{c}* 300 \pm 16 \\
\dagger 68 \pm 4\end{array}$ & $\begin{array}{l}5.9 \pm 0.8 \\
6.4 \pm 1.2\end{array}$ & $\begin{array}{l}31.2 \pm 2.8 \\
18.0 \pm 2.7\end{array}$ & $85 \pm 10$ & $8 \cdot 0 \pm 1 \cdot 3$ & $12 \cdot 6 \pm 1 \cdot 2$ \\
\hline H41 & $\begin{array}{c}429 \\
(205-517)\end{array}$ & $\begin{array}{c}49.9 \\
(40-59)\end{array}$ & $\begin{array}{c}1792 \\
(1317-2459)\end{array}$ & $175 \pm 22$ & $47 \pm 4 \cdot 7$ & $1234 \pm 65$ & & Not availab & le \\
\hline
\end{tabular}

* Testicular tissue
+ Ovarian tissue.

Injection of PMSG failed to initiate oestrous cycles, and swelling of the vulva was not provoked.

\section{Morphology of genitalia and gonads}

Each animal had a much enlarged and prominent clitoris, although reflection of the vulval lips was necessary for full exposure of this structure (Pl. 1, Fig. 1). The posterior vagina was smaller than usual, and the cervix was of a relaxed muscular arrangement rather than oedematous as in oestrous gilts. A morphologically normal bicornuate uterus was present in each instance (Pl. 1, Figs 2 and 3), and the horns were patent to fluid flow when examined at autopsy. However, the duct system anterior to the uterine horns was abnormal except on the right-hand side of one tract (B17, Pl. 1, Fig. 3), where the oviduct was fully developed, 
terminating in a fimbriated infundibulum (Pl. 1, Fig. 4). Otherwise, the oviducts were largely ill-defined or vestigial, though a portion of the isthmus could be distinguished (Pl. 1, Figs 5 and 6 ); this was of a size and diameter characteristic of prepubertal animals. An ampullary portion was not evident, whereas a highly coiled structure was considered to be a Wolffian duct derivative and closely resembled epididymal tissue (Pl. 1, Figs 4-6). Development of seminal vesicles, prostate and Cowper's glands was not detected macroscopically.

The gonads were of unusual form in each of the 3 animals. The most conspicuous feature was the mass of 'homogeneous' reddish-brown tissue that comprised approximately $95 \%$ of each gonad in K12 (Pl. 1, Fig. 2) and 80\% of each gonad in H41 (Pl. 1, Fig. 5). The remaining gonadal tissue resembled ovarian tissue with many vesicular follicles of $1.0-1.5 \mathrm{~mm}$ diameter visible on the surface: these were clear-walled in $\mathrm{H} 41$ but haemorrhagic in K12. In both animals, the ovarian tissue was located adjacent to the ovarian stalk. Injection of PMSG had failed to stimulate development of the vesicular follicles, and there was no evidence of any previous ovulations.

In animal B17, one of the gonads was an apparently normal ovary enveloped by the fimbriated extremity of the oviduct (P1. 1, Fig. 4). Displacement of the fimbria during surgery revealed corpora albicantia and 16 follicles of a $9-10 \mathrm{~mm}$ preovulatory diameter (Pl. 1, Fig. 3). When examined at autopsy 6 days later, these follicles had ovulated and were developing corpora lutea. The contralateral gonad was a reddish-brown mass reminiscent of testicular tissue, adjoining which there was extensive development of a structure resembling an epididymis (P1. 1, Fig. 4).

\section{Histology}

The major portion of the intersex gonads consisted of testicular tissue which was superficially similar to, although smaller than, that in normal males. The extensive seminiferous tubules did not have a central canal or lumen (PI. 2, Fig. 7) and the cells were only of the somatic

\section{PLATE 1}

Morphology of the reproductive tract and gonads in 3 intersex pigs, each of which was a genetic female.

Fig. 1. Distension of the vulval lips to expose the prominent clitoris.

Fig. 2. Post-mortem display of the reproductive tract and gonads. The latter consist almost entirely of testis-like tissue whilst the uterus is of normal bicornuate form and patent.

Fig. 3. A bicornuate uterus exposed at laparotomy. The left gonad is composed principally of testis-like tissue in contrast to the functional ovary and adjoining oviduct on the contralateral side.

Fig. 4. The ovary portrayed in Fig. 3 enveloped by the fimbriated extremity of the oviduct. Note the epididymal tissue adjoining the ovotestis that forms the left gonad.

Figs 5 and 6. Ovotestes to illustrate the limited extent of the ovarian tissue in 2 animals. The isthmic portion of the oviduct extends rostrally from the utero-tubal junction.

\section{PLATE 2}

Fig. 7. Testicular portion of the ovotestis of an intersex pig. The seminiferous tubules are devoid of germ cells and contain cells which resemble Sertoli cells whilst the well developed interstitial tissue is composed of typical Leydig cells. $\times 190$.

Fig. 8. Graafian follicle within the ovarian part of the ovotestis shown in Fig. 7. The membrana granulosa is of normal appearance but the theca interna is absent. $\times 190$.

Fig. 9. Efferent ductules of the epididymis in an intersex pig. These contain fibrous elements but note the absence of spermatozoa. $\times 100$.

Fig. 10. High power photomicrograph of epididymal tissue in an intersex pig. $\times 190$. 
PLATE 1
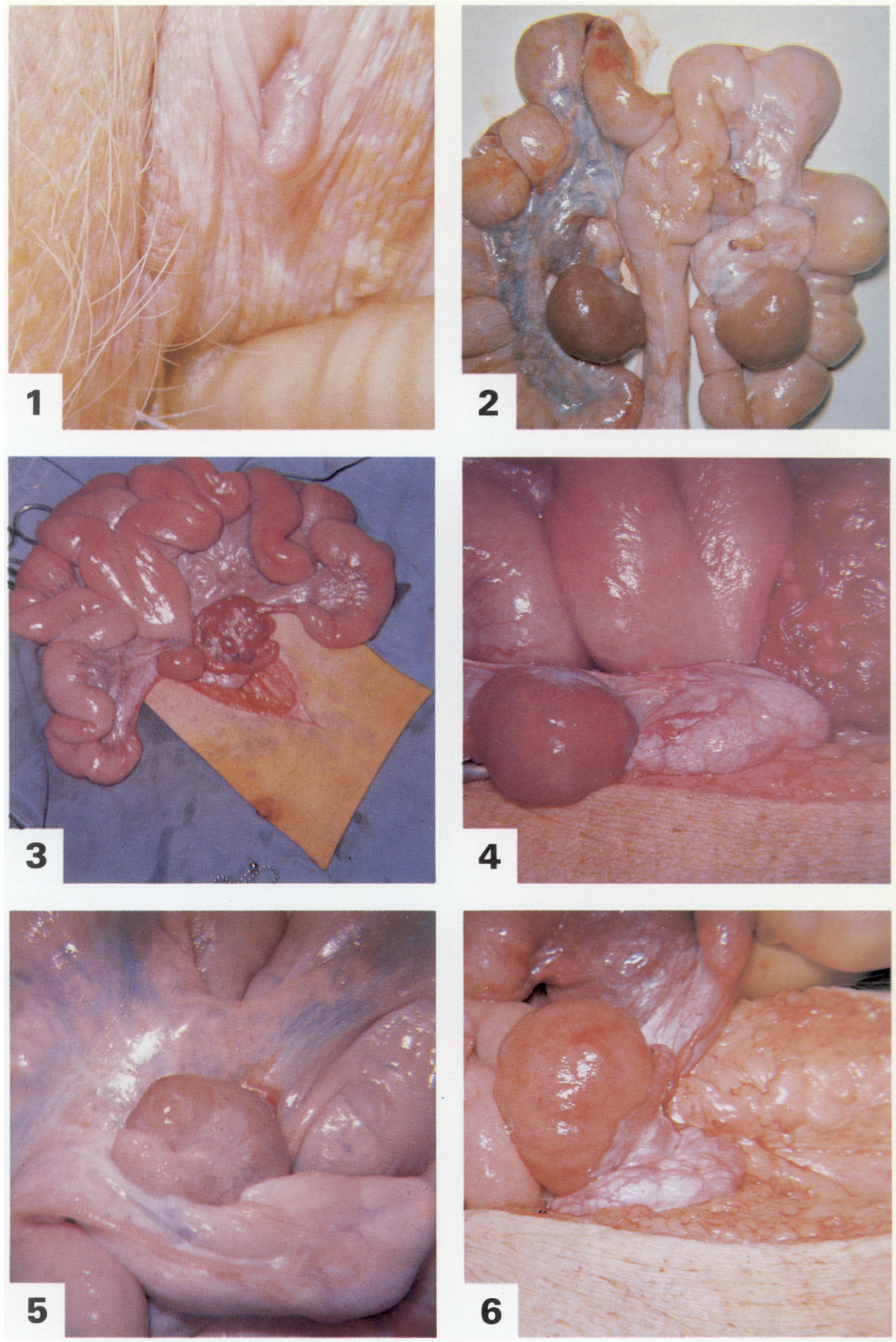
PLATE 2
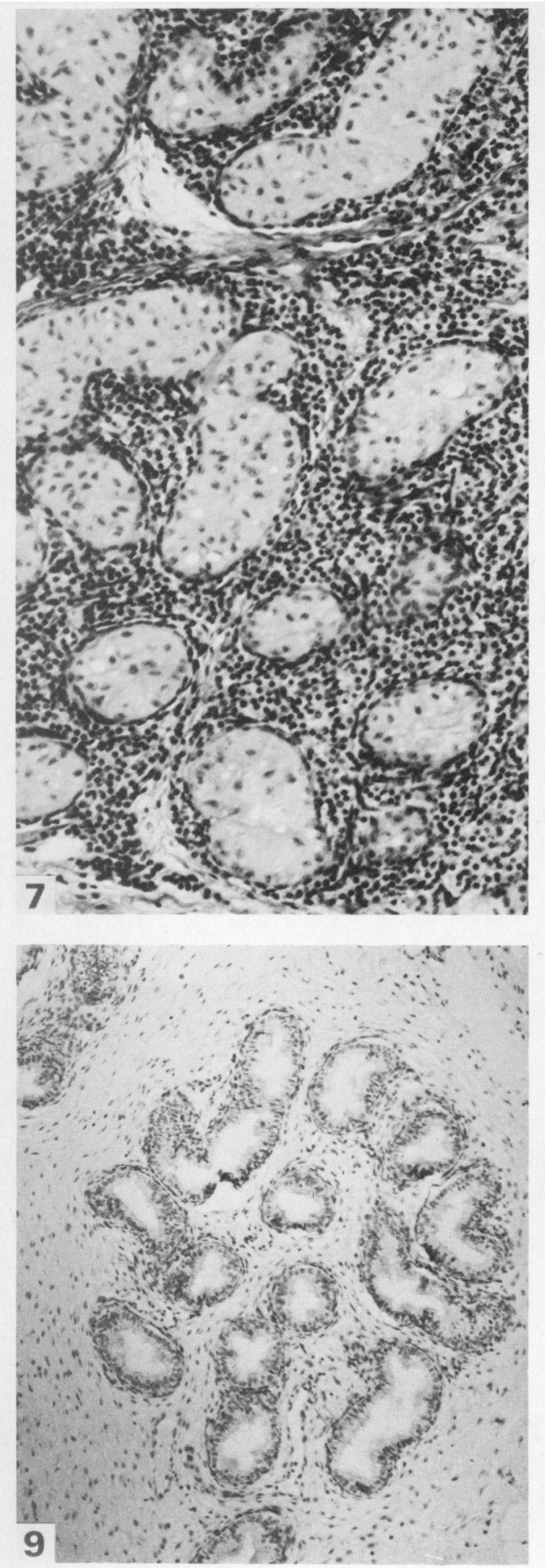
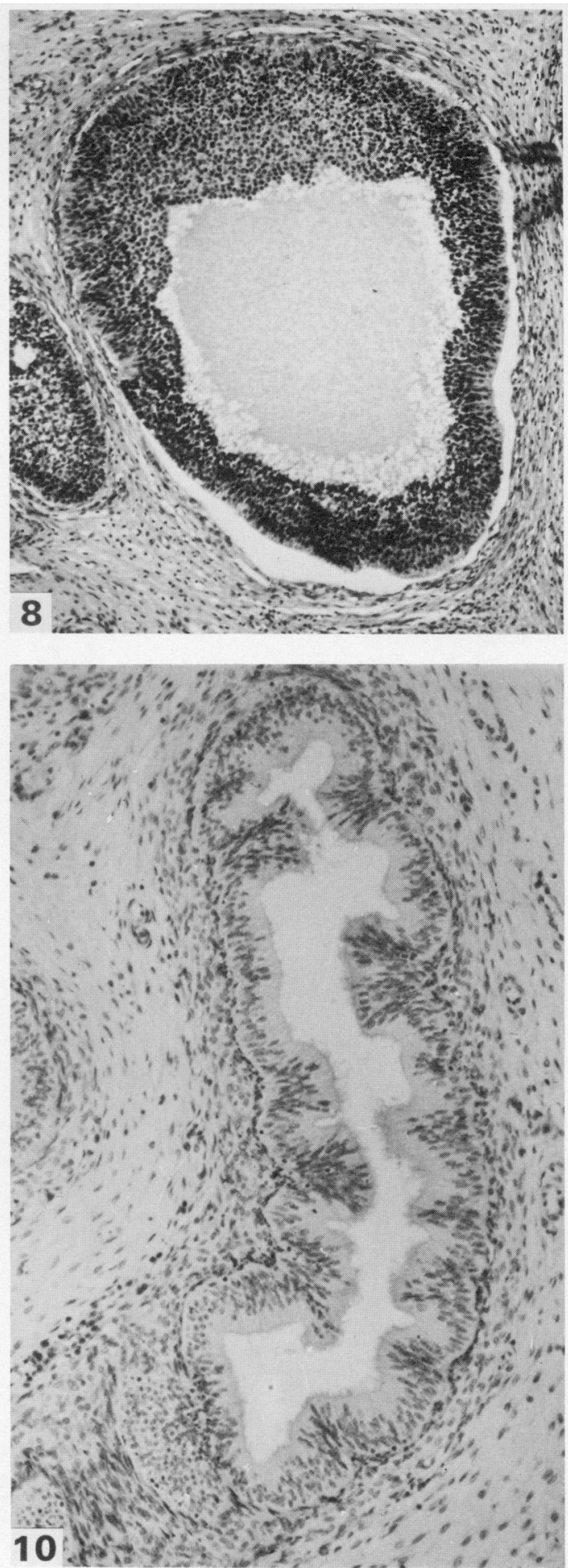
type: germ cells were never detected. The somatic cells within the seminiferous tubules were large and stained palely. Their histology differed from that of granulosa cells and was more typical of the Sertoli cells of normal males. The spaces between adjacent seminiferous tubules were packed with small cells with darkly staining nuclei and were similar to the Leydig cells seen in the testes of $\mathrm{XY}$ individuals.

The ovarian tissue of intersex gonads contained all stages of follicular growth including small antral (Graafian) follicles. Irrespective of the size of the follicle, the granulosa cells were morphologically similar to those seen in comparable follicles within ovaries of control females (Pl. 2, Fig. 8), although the theca interna was poorly developed or even absent.

Well developed rete testis tubules could be identified and these were associated with an extensive epididymis (Pl. 2, Figs 9 and 10).

\section{Steroid hormones}

Our brief observations are summarized in Table 2. Concentrations of testosterone in plasma were about one-tenth of those found in normal males (see Ellendorff et al., 1975), but oestradiol concentrations approached those found before a normal ovulation (see Hansel, Concannon \& Lukaszewska, 1973). Although the progesterone concentrations in the plasma of the 2 animals appear very different, they are both low, being of the order of that found in the follicular phase of the porcine oestrous cycle (Hansel et al., 1973). Androstenedione and oestrone were present in the plasma of $\mathrm{H} 4 \mathrm{l}$ but were not measured.

\section{Discussion}

Even though the genetic sex of these animals was unequivocally female, behavioural, histological and endocrinological components of maleness have been demonstrated. Pronounced development of the clitoris and aggressive behaviour could be explained by the role of circulating androgens, and if such steroids were available from Leydig cells during differentiation of the embryo, then this could also explain partial retention of the Wolffian ducts. By contrast, suppression of the Müllerian ducts requires a separate testicular factor, thought to be secreted by the Sertoli cells (Josso, Picard, Dacheux \& Courot, 1979), and the incomplete differentiation of these cells would be compatible with development of most of the female duct system. The primary aberration giving rise to the intersex condition would therefore appear to be associated with formation of the primitive gonad, but the manner in which this develops as an ovo-testis, sometimes unilaterally, in an XX animal is unknown. Transplacental migration of a small number of cells from a neighbouring male embryo would seem one possibility, assuming that a limited degree of fusion had occurred in the allanto-chorionic membranes. However, as no evidence of chimaerism or of a Y chromosome was revealed and germ cells could not be detected in the seminiferous tubules, more subtle explanations may be required, perhaps invoking translocation of part of a $\mathrm{Y}$ on to an $\mathrm{X}$ chromosome or a role for autosomal genes. Surgical attempts to promote fusion of the embryonic sacs with subsequent vascular anastomosis might offer one approach to clarifying the aetiology of intersex pigs.

Although vesicular (Graafian) follicles were present in the ovo-testes, these did not appear to respond to PMSG and the theca was poorly developed. This suggests that the follicles were in some manner abnormal, or unable to respond to gonadotrophins in the presence of neighbouring 'testicular' tissue, perhaps because of an absence of available receptors or of elevated concentrations of androgens; indeed, these latter two points may be functionally related.

Incidental observations on intersex pigs are not new (see Cox, 1968; Scofield, Cooper \& Lamming, 1969; Krishnamurthy, Macpherson \& King, 1971; Booth \& Polge, 1976), and there are also classical histological studies (e.g. Baker, 1925; Brambell, 1929). However, the approach 
of combining observations on the morphology, histology and endocrinology of these animals is one we intend to apply systematically in the future.

This study was supported by grants from the Agricultural Research Council and the Ford Foundation. We are particularly grateful to Dr Ann Chandley and Judith Fletcher for the karyotype analyses and to Robert Nichol and Anne Kelly for technical assistance.

\section{References}

Baker, J.R. (1925) On sex-intergrade pigs: their anatomy, genetics, and developmental physiology. $J$. exp. Biol. 2, 247-263.

Biggers, J.D. (1968) Aspects of intersexuality in domestic mammals. Proc. 6th Int. Congr. Anim. Reprod. \& A.I., Paris 2, 841-870.

Biggers, J.D. \& McFeely, R.A. (1966) Intersexuality in domestic mammals. Adv. Reprod. Physiol 1, 29-59.

Bishop, M.W.H. (1972) Genetically determined abnormalities of the reproductive system. J. Reprod. Fert., Suppl. 15, 51-78.

Booth, W.D. \& Polge, C. (1976) The occurrence of C 19 steroids in testicular tissue and submaxillary glands of intersex pigs in relation to morphological characteristics. J. Reprod. Fert. 46, 115-121.

Brambell, F.W.R. (1929) The histology of an hermaphrodite pig and its developmental significance. $J$. Anat. 63, 397-407.

Breeuwsma, A.J. (1970) Studies on intersexuality in pigs. Doctoral thesis, Drukkerij Bronder-Offset N.V., Rotterdam.

Buckland, R.A., Fletcher, J.M. \& Chandley, A.C. (1976) Characterisation of the domestic horse (Equus caballus) karyotype using $\mathrm{G}$-and $\mathrm{C}$-banding techniques. Experientia 32, 1146-1149.

Cook, B., Hunter, R.H.F. \& Kelly, A.S.L. (1977) Steroid-binding proteins in follicular fluid and peripheral plasma from pigs, cows and sheep. $J$. Reprod. Fert. 51, 65-71.
Cox, J.E. (1968) A case of a fertile intersex pig. $J$. Reprod. Fert. 16, 321-322.

Deas, D.W., Melrose, D.R., Reed, H.C.B., Vandeplassche, M. \& Pidduck, H. (1979) Other noninfectious abnormalities. In Fertility and Infertility in Domestic Animals, 3rd edn, ch. 7, pp. 137-159. Ed. A. J. Laing. Baillière Tindall, London.

Ellendorff, F., Parvizi, N., Pomerantz, D.K., Hartjen, A., Konig, A., Smidt, D. \& Elsaesser, F. (1975) Plasma luteinizing hormone and testosterone in the adult male pig: 24 hour fluctuations and the effect of copulation. J. Endocr. 67, 403-410.

Hansel, W., Concannon, P.W. \& Lukaszewska, J.H. (1973) Corpora lutea of the large domestic animals. Biol. Reprod. 8, 222-245.

Josso, N., Picard, J.Y., Dacheux, J.L. \& Courot, M. (1979) Detection of anti-Mullerian activity in boar rete testis fluid. J. Reprod. Fert. 57, 397-400.

Krishnamurthy, S., Macpherson, J.W. \& King, G.J. (1971) Intersexuality in Ontario swine. Canad. J. Anim. Sci. 51, 807-809.

Scofield, A.M., Cooper, K.J. \& Lamming, G.E. (1969) The distribution of embryos in intersex pigs. $J$. Reprod. Fert. 20, 161-163.

Short, R.V. (1969) An introduction to some of the problems of intersexuality. J. Reprod. Fert., Suppl. 7, $1-8$.

Received 30 April 1981 